\title{
Better policies for SMEs to scale up and go global
}

Written by: Lamia Kamal-Chaoui, Director, Centre for Entrepreneurship, SMEs, Local Development and Tourism, OECD

Last update: 28 January 2020

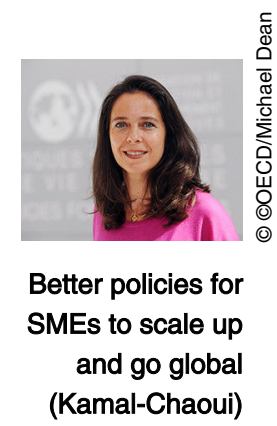

Many OECD countries are seeking to scale up the performance of small and medium-sized enterprises (SMEs). They already generate around $70 \%$ of total employment. On average, they account for $50-60 \%$ of gross value added in the OECD area, and more than $80 \%$ in countries such as Italy, Greece and Korea. SMEs range from local micro-enterprises to "born global" technology leaders and firms whose raison d'être from the moment they are founded is to operate internationally. These smaller firms are essential for achieving societal goals of productivity growth and greater inclusion, but many face challenges in making the most of today's opportunities. How can policy better help them scale up and go global?

Going global and participating in global value chains is one way to boost productivity and scale up. Research shows that firms experience productivity increases after entering international markets by benefiting from scale economies, knowledge exchange and technical spillovers. In African countries, for example, exporting has been found to raise productivity by more than $25 \%$. However, SMEs export less relative to their share in the national economy, accounting for only $20-40 \%$ of exports versus over half of value added. But exporting need not be the be-all and end-all for SMEs. Often, they sell products to exporters who are part of global value chains, and while the SMEs are not themselves exporting, that involvement gives these smaller firms productivityenhancing access to information and technology. 
Robust SMEs help workers, first and foremost, by creating jobs. In some regions, smaller businesses may be the only source of private sector employment. The share of young SMEs in total job creation is about twice as large as their share in total job destruction. Established medium-sized companies that scale up, which often involves going global, are a driving force for job creation as well as competitiveness. And, salaries and working conditions are almost always better in firms engaged in international trade.

Improving the business environment for SMEs is critical. A sound regulatory environment, which benefits all businesses, is especially important for smaller businesses. Regulatory uncertainty, complexity, and inconsistencies, including differences in regulations across countries, affect SMEs disproportionately more than large firms. Other elements of the business environment such as contract enforcement, civil justice systems, bankruptcy regimes, and corruption in the public sector also especially hurt smaller companies.

OECD work shows that SMEs have experienced better access to international markets in recent years thanks to trade and investment openness, and physical and IT infrastructure. However, obstacles and inefficiencies remain. Measures discriminating against foreign suppliers are still in place in a large number of countries. Barriers to entry are especially high in services sectors, such as professional services, where there are many SMEs. For cross-border exports of services, an average level of services trade-restrictiveness represents the equivalent of an additional $14 \%$ tariff for SMEs relative to large firms. Predictable and efficient customs procedures and logistics services are also especially important for SMEs. Reform of slow or cumbersome border procedures can cut costs of trading for all firms by $12-18 \%$.

Access to the right type of finance is another factor in helping SMEs scale up. Targeted policies can address failures in financial markets, which typically limit access to appropriate forms of finance by SMEs and start-ups. Despite improving economic conditions, new bank lending to SMEs fell in 15 out of 25 countries in 2016 with SMEs turning increasingly to alternative sources of financing such as venture capital investment, crowdfunding and leasing. Still, the potential of nonbank finance instruments to serve SMEs remains underdeveloped in most countries. The G20/OECD High Level Principles on SME Financing can guide countries in the development of such strategies.

Digitalisation can open up new opportunities to participate in the global economy. Digital technologies allow SMEs to improve market intelligence, reach scale without mass, and access distant markets and knowledge networks at relatively low cost. In most countries the gap between large firms and SMEs in adopting simple internet connectivity and web presence is narrow. However, SMEs are only half as likely as large firms to participate in e-commerce or use cloud computing. The adoption lag is mainly due to lack of investment in complementary 
knowledge-based assets such as research and development (R\&D), human resources, organisational changes and process innovation.

Other policy efforts can help address obstacles within firms, including the development of strategic competencies to take advantage of digitalisation and globalisation. But accessing needed resources such as skills, finance, knowledge and technology requires that SMEs take the initiative to do so themselves. The OECD reviews of SME and Entrepreneurship Policy in countries such as Canada, Israel, Italy, Mexico and the Russian Federation show there is growing attention to consultancy, mentoring, and assistance to support technological, organisational and marketing innovation to help firms upskill and upgrade.

Regional and local policies can also have an important impact on SME performance. Firms in local clusters are among the most successful in making the leap to international trade. By geographically concentrating skills, innovation projects, and strong social capital links to help knowledge flow on key technologies and market opportunities, local clusters are high productivity environments.

Good SME policy should function as an umbrella, cutting across the boundaries of different ministries and government agencies. Continued effort is needed to better understand the combined effects of structural reforms on the SME business environment, as well as the role and impact of policies targeted to these smaller companies.

COOECD Observer No 313, Q1 2018

\section{References}

OECD (2018), Financing SMEs and Entrepreneurs 2018: An OECD Scoreboard, OECD Publishing, Paris. http://dx.doi.org/http://dx.doi.org/10.1787/ fin_sme_ent-2018-en

OECD (2017), Small, Medium, Strong. Trends in SME Performance and Business Conditions, OECD Publishing, Paris. http://dx.doi.org/http://dx.doi.org/ 10.1787/9789264275683-en

OECD (2017), SME and Entrepreneurship Policy in Canada, OECD Publishing, Paris. http://dx.doi.org/http://dx.doi.org/10.1787/9789264273467-en 